(СТ. О. ПЕРЦЕВА, Л. І. КОНОПКІНА, Т. В. КІРЕЄВА, К. Є. БОГАЦЬКА, О. Г. ЧЕРКАСОВА, О. В. МИРОНЕНКО, О. В. ФЕСЕНКО, Л. А. БОТВІНІКОВА, К. О. БЄЛОСЛУДЦЕВА

\title{
Впровадження інновацій у педагогічний процес - шлях до розбудови вищої медичної школи України
}

Мета роботи: визначити ефективність впровадження інноваційних технологій у педагогічний процес на кафедрі внутрішньої медицини 1 ДЗ “ДМА”.

“Інноваційна діяльність представляє собою систему взаємопов'язаних видів робіт, сукупність яких забезпечує появу дійсних інновацій”

О.В. Бондаренко

“Інноваційна освіта” - це освіта, яка, поперше, створює умови для повноцінного розвитку усіх її учасників, а, по-друге, сприяє саморозвитку кожного з них. Це освіта, що розвиває і розвивається.

Однією з найсуттєвіших проблем підготовки спеціалістів із вищою освітою $є$ компетентність викладачів, які забезпечують навчальний процес. Дослідження останніх десятиліть ХX ст. у галузі педагогіки вищої школи показали, що до навчального процесу з різних напрямів залучається велика кількість осіб (понад 70 \%) без фахового та педагогічного досвіду. Більшість з них не має педагогічної освіти, тому й не володіє методикою навчання дисциплін i, як наслідок, здійснює свою викладацьку діяльність на ситуативно-творчому рівні. Лише поодинокі викладачі володіють концептуально-творчим стилем діяльності й здатні якісно реалізовувати дидактичні матеріали навчального процесу, впливаючи при цьому і на виховну складову [1, 2, 3, 4].

Таким чином, перед викладачами старшого покоління вже сьогодні постають нагальні запитання: хто вони, майбутні доценти й професори медичної науки, що вже сьогодні можна їм запропонувати задля кращої наукової, педагогічної та фахової реалізації у майбутньому, які поради, вказівки, настанови їм можна надати, яким чином їх підтримати, вказавши правильний вектор подальшого удосконалення?

3 огляду на усе вищезазначене у 2017 р. на кафедрі внутрішньої медицини 1 Державного закладу “Дніпропетровська медична академія Міністерства охорони здоров’я України” (ДЗ “ДМА”) були започатковані три професійні школи: “Школа молодого науковця”, “Школа молодого викладача” та “Школа клініциста”.
Методики дослідження: інтерактивне опитування респондентів (молодих викладачів, науковців, аспірантів, магістрантів, клінічних ординаторів, лікарів-інтернів, лікарів-терапевтів закладів практичної охорони здоров’я) після відвідування ними засідань професійних шкіл.

“Школа молодого науковця" - інноваційний освітянський “бренд” кафедри в підготовці науково-педагогічних кадрів.

Задля якісної підготовки майбутніх викладачів-науковців професори кафедри проводить заняття 3 аспірантами за технологіями міжнародних інноваційних навчально-тренінгових програм, 30крема стовно технологій написання та принципів оформлення наукової і науково-дослідної літератури (статей, тез, патентів, інформаційних листів, галузевих нововведень тощо). Ми проводимо як індивідуальні, так і групові заняття.

Професори й доценти, пройшовши у 2016 р. курси лекторської майстерності, навчають цим основам як аспірантів, так і клінічних ординаторів. При цьому велику увагу приділяють розвитку соціалізації молоді, яка навчається шляхом участі у творчих наукових конкурсах.

На кафедрі забезпечений вільний доступ аспірантів до електронних бібліотек та інформаційних ресурсів.

“Школа молодого викладача" - інноваційний підхід до розбудови закладу.

Практично ніхто з викладачів, включно й молодих, котрі приходять на терени педагогічної діяльності здебілышого після закінчення аспірантури, не має достатньої педагогічної освіти. Останнє пояснюється тим, що під час навчання молодого фахівця в аспірантурі основна увага приділяється його дослідницькій діяльності, а не педагогічній. 3 іншого боку, курси, факультети та інститути підвищення кваліфі- 
кації викладачів спрямовані на розвиток умінь і навичок або в галузі дисциплін, що викладаються, або у сфері інформаційних технологій. До того ж, не зважаючи на існування великої кількості спеціальної літератури з педагогіки, яка доступна і в бібліотечних фондах, і на електронних ресурсах, викладачі не завжди вміють нею користуватися. Нові ж пріоритети вітчизняної освіти спрямовані на запровадження спеціальної професійної підготовки насамперед молодих викладачів для роботи у вищій школі.

У рамках започаткованої “Школи молодого викладача” відбувається модернізація змісту професійної підготовки аспірантів та молодих викладачів, які щойно закінчили аспірантуру, до праці в умовах Нової української вищої медичної школи. Молодь відвідує лекції, практичні та семінарські заняття, що їх проводять досвідчені викладачі, бере участь у методичних нарадах, групових тренінгах з оволодіння практичними навичками на муляжах, вчиться принципам складання тестових завдань “Крок”.

“Школа клініциста" - інноваційна форма післядипломної освіти.

До роботи цієї школи залучаються не лише аспіранти, магістранти, клінічні ординатори, лікарі- інтерни, а й досвідчені викладачі та лікарі лікувально-профілактичних закладів, що є клінічними базами кафедри. На засіданнях обговорюються та детально аналізуються найбільш складні клінічні випадки, розбираються діагностичні й лікувальні помилки, виносяться колегіальні рішення. Школа $\epsilon$ необхідним підгрунтям до професійного зросту усіх викладачів-клініцистів. Проводять засідання професори та доценти кафедри.

За результатами опитування респондентів після кожного проведеного засідання будь-якої започаткованої “школи” було показано, що впровадження вищезазначених інноваційних технологій у педагогічний процес призводить до підвищення рівня знань, а також професійної майстерності молодих викладачів, аспірантів, магістрантів, клінічних ординаторів медичного вузу та лікарів-інтернів і лікарів-терапевтів закладів практичної охорони здоров'я.

Державний заклад “Дніпропетровська медична академія МОЗ України” має потужний арсенал різних педагогічних інновацій, які можуть бути широко використані при розбудові вищої медичної школи в Україні.

\section{СПИСОК ЛІТЕРАТУРИ}

1. Педагогічна майстерність: хрестоматія : [навч. посіб.] / Упоряд. : І. А. Зязюн, Н. Г. Базилевич, Т. Г. Дмитренко ; За ред. І. А. Зязюна. - К. : СПД Богданова А. М., 2008. - 462 с. 2. Постижение педагогической культуры человечества: в 2 т. Отечественная педагогическая традиция / Под. ред.

\section{REFERENCES}

1. Ziaziun, I.A., Bazylevych, N.H., \& Dmytrenko T.H. (2008). Pedahohichna maisternist: Khrestomatiia: navch. posib. [Pedagogical skills: Hermes: manual]. Ziaziun, I.A. (Ed.) Kyiv: SPD Bohdanova A.M. [in Ukrainian].

2. Kornetova, G.B. (Ed.). (2010). Postizhenye pedagogicheskoy kultury chelovechestva. Otechestvennaya pedagogicheskaya traditsiya [The comprehension of the pedagogical culture of

Г. Б. Корнетова. - АСОУ, 2010. - Т. 2. - 248 с.

3. Лавріненко О.А. Історія педагогічної майстерності / О. А. Лавріненко. - К. : СПД Богданова А. М., 2009. - 328 с. 4. Новолокова Н. П. Енциклопедія педагогічних технологій та інновацій / Н. П. Новолокова. - Х. : “Основа”, 2012. - 176 с.

mankind. Domestic pedagogical tradition]. ASOU [in Russian]. 3. Lavrinenko, O.A. (2009). Istoriia pedahohichnoi maisternosti [History of pedagogical mastery]. SPD Bohdanova A.M. [in Ukrainian].

4. Novolokova, N.P. (2012). Entsyklopediia pedahohichnykh tekhnolohii ta innovatsii [Encyclopedia of pedagogical technologies and innovations]. Kharkiv: “Osnova” [in Ukrainian].

Отримано 29.05.2018 
T. O. PERTSEVA, L. I. KONOPKINA, T. V. KIREYEVA, K. Y. BOGATSKA, O. G. CHERKASOVA, O. V. MYRONENKO, O. V. FESENKO, L. A. BOTVINIKOVA, K. O. BELOSLUDCEVA

Dnipropetrovsk Medical Academy

\section{IMPLEMENTATION OF INNOVATIONS INTO PEDAGOGICAL PROCESS - THE WAY TO DEVELOPMENT OF HIGHER MEDICAL SCHOOL IN UKRAINE}

The aim of the work: to define the efficiency of implementation of innovative technologies into pedagogical process at the Department of Internal Medicine 1 of Dnipropetrovsk Medical Academy.

Т. А. ПЕРЦЕВА, Л. И. КОНОПКИНА, Т. В. КИРЕЕВА, Е. Е. БОГАЦКАЯ, О. Г. ЧЕРКАСОВА, Е. В. МИРОНЕНКО, А. В. ФЕСЕНКО, Л. А. БОТВИНИКОВА, К. О. БЕЛОСЛУДЦЕВА

Государственное учреждение “Днепропетровская медицинская академия Мз Украины”

\section{ВНЕДРЕНИЕ ИННОВАЦИЙ В ПЕДАГОГИЧЕСКИЙ ПРОЦЕСС - ПУТЬ К РАЗВИТИЮ ВЫСШЕЙ МЕДИЦИНСКОЙ ШІКОЛЫ В УКРАИНЕ}

Цель работы: определить эффективность внедрения инновационных технологий в педагогический процесс на кафедре внутренней медицины 1 ГУ “ДМА”. 